\title{
Rapid effects of progesterone on ciliary beat frequency in the mouse fallopian tube
}

\author{
Anna Bylander ${ }^{1}$, Magdalena Nutu', Rikard Wellander², Mattias Goksör2 ${ }^{2}$, Håkan Billig ${ }^{1}$ and DG Joakim Larsson*1
}

\begin{abstract}
Background: The physiological regulation of ciliary beat frequency (CBF) within the fallopian tube is important for controlling the transport of gametes and the fertilized ovum. Progesterone influences gamete transport in the fallopian tube of several mammalian species. In fallopian tubes isolated from cows, treatment with 20 micromolar progesterone caused a rapid reduction of the tubal CBF. The aims of this study were to establish methodology for studying fallopian tube CBF in the mouse, as it is an important model species, and to investigate if progesterone rapidly affects the CBF of mice at $\mathrm{nM}$ concentrations.
\end{abstract}

Methods: A method to assess tubal CBF of mice was developed. Fallopian tubes were dissected and the tissue was cut in small pieces. Tissue samples with moving cilia were located under an inverted bright field microscope and held still against the bottom of a petri dish by a motorized needle system. Images were acquired over 90 minutes at 35 degrees $C$ with a high-speed camera and used for assessing changes in the CBF in response to the addition of hormone.

Results: The baseline CBF of the mouse fallopian tube was $23.3+/-3.8 \mathrm{~Hz}$. The CBF was stable over at least 90 minutes allowing establishment of a baseline frequency, addition of hormone and subsequent recordings. Progesterone at concentrations of 20 micromolar and $100 \mathrm{nM}$ significantly reduced the CBF by $10 \%$ and $15 \%$ respectively after 30 minutes compared with controls.

Conclusions: The present study demonstrates that the mouse, despite its small size, is a useful model for studying the fallopian tube CBF ex vivo. The rapid reduction in CBF by $100 \mathrm{nM}$ progesterone suggests that gamete transport in the fallopian tube could be mediated by progesterone via a non-genomic receptor mechanism.

\section{Background}

The epithelium of the mammalian fallopian tube consists mainly of two cell types, ciliary and secretory cells. The transport of gametes is aided by ciliary movements and muscular contractions where the cilia seem to play a dominant role [1,2]. Regulation of ciliary motility is therefore important to facilitate the meeting of gametes and the subsequent transport of the fertilized ovum to its implantation site. Several factors have been reported to affect tubal ciliary motility including progesterone $\left(\mathrm{P}_{4}\right)$ [3-6], estradiol [3], interleukin 6 [7], prostaglandins [8,9], angiotensin II [10] and $\mathrm{Ca}^{2+}[11]$.

\footnotetext{
* Correspondence: joakim.larsson@fysiologi.gu.se

${ }^{1}$ Institute of Neuroscience and Physiology, the Sahlgrenska Academy,

University of Gothenburg, SE-405 30 Göteborg, Sweden
}

Full list of author information is available at the end of the article
Progesterone has been proposed to regulate ciliary beat frequency (CBF) in the fallopian tube of several mammalian species [3-6]. For example, treatment with $\mathrm{P}_{4}(10 \mu \mathrm{M})$ reduced the CBF of humans by $40-50 \% 24$ hours post treatment ex vivo [3]. The effect of $\mathrm{P}_{4}$ was reversed by RU486, a nuclear progesterone receptor antagonist, suggesting an action via the classical nuclear receptor [3]. To our best knowledge, possible rapid effects of $\mathrm{P}_{4}$ on fallopian tube CBF have yet not been studied in humans. However, Wessel et al. showed that $20 \mu \mathrm{M}$ of $\mathrm{P}_{4}$ reduced the CBF by $11 \%$ within 15 minutes in dissected fallopian tubes from cows. Furthermore, this effect was not reversed by RU486, which supports the involvement of another receptor than the nuclear progesterone receptor [12]. 
Possible mediators of these effects are the membrane progesterone receptors $(\mathrm{mPR} \alpha, \quad \beta$ and $\gamma)$ initially described by $\mathrm{Zhu}$ et al. $[13,14]$. Upon $\mathrm{P}_{4}$ stimulation, mPRs have been proposed to regulate oocyte maturation $[15,16]$, gonadotropin secretion [17], control of myometrial functions [18] and sperm motility [19] via interactions with G-proteins. Our previous reports demonstrated the presence of $\mathrm{mPR} \beta$ and $\mathrm{mPR} \gamma$ in the ciliated epithelial cells of the mouse and human fallopian tube, proposing an involvement of these receptors in the control of tubal ciliary activity in these species $[20,21]$. In the mouse fallopian tube the expression of both receptors was regulated after $\mathrm{P}_{4}$ administration [21].

Although there are many studies on tubal ciliary activity in larger mammals such as cows [12], humans [3] and rabbits [22], we have not been able to find any studies on fallopian tube CBF in mice. This species would be valuable to study, as their general physiology is well studied and the mouse provide superior opportunities for studying the involvement of different gene products through the availability of genetically modified strains. The ultrastructure of the fallopian tube is similar between mice and humans, including the distribution of mPRs [20,21]. Despite the considerable difference in length, the duration of egg transport in the fallopian tube is approximately equal between these species [23]. Mice are easy to manipulate and readily available, therefore it would be worthwhile to investigate their utility as models for studying the mechanisms behind $\mathrm{P}_{4}$-regulated $\mathrm{CBF}$ in the mammalian fallopian tube. It is important to develop models to unravel mechanisms regulating the transport of gametes, as dysfunctions of the fallopian tube might lead to, for example, ectopic pregnancies or other forms of infertility [24].

The first aim of this study was therefore to establish a method to analyze the CBF ex vivo in mice. A second aim was to investigate if $\mathrm{P}_{4}$ causes a rapid reduction in $\mathrm{CBF}$ similar to the situation in cow [12]. In these earlier studies $20 \mu \mathrm{M}$ of $\mathrm{P}_{4}$ was used. This is a rather high concentration, given that the affinities for progesterone of both nuclear [22] and membrane progesterone receptors [11] are within the nM range. Therefore, we also wanted to investigate possible effects at $\mathrm{nM}$ concentrations in the mouse.

\section{Methods}

\section{Tissue collection and sample preparation}

Fallopian tubes were obtained from immature (3.5-5 weeks-old) female C57BL/6 mice from Charles River, Kisslegg, Germany. The animals were kept under a 12:12$\mathrm{h}$ light-dark schedule at $21 \pm 2^{\circ} \mathrm{C}$ with ad libitum access to chow and water. Animals were allowed to acclimate to the animal facilities for $\geq 5$ days before initiation of experiment. The mice were killed by cervical dislocation and both fallopian tubes were dissected out and washed in PBS (Phosphate Buffer Saline, pH 7.0). After removal of the broad ligament, fat and blood vessel the fallopian tubes were transferred to petri-dishes containing $37^{\circ} \mathrm{C}$ pre-warmed G-MOPS ${ }^{\text {ma }}$ Plus-medium (Vitrolife, Gothenburg, Sweden). This medium is designed to support the handling and manipulation of oocytes and embryos in an air atmosphere.

Small fallopian tube segments reaching from the ampullary to the infundibulum region were then cut and retransferred to fresh medium. The tube-like segments were longitudinally opened and chopped in smaller pieces. After an additional washing step the samples were kept in medium at $35^{\circ} \mathrm{C}$ until measurements. The experiments were approved by the local animal ethics committee in, Gothenburg, Sweden (246/2007 and 392/2008) to Joakim Larsson.

The CBF recordings were carried out on tissue samples on the day after sampling at a temperature of about $35^{\circ} \mathrm{C}$. The samples were placed in petri dishes $(35 \mathrm{~mm})$ with glass bottom microwells $(14 \mathrm{~mm})$ (MatTek Corporation, Ashland, USA) containing $2 \mathrm{ml}$ of pre-warmed GMOPS $^{\mathrm{Tx}}$. To be able to add hormone and distribute it evenly in the dish while measuring the CBF, the samples must be prevented from moving. After trying out different methods, the best alternative found was pressing a piece of a tissue sample against the bottom of the petri dish using a sterilized needle (TransferTip, iD $15 \mu \mathrm{m}$, oD $20 \mu \mathrm{m}$, Eppendorf AG, Hamburg, Germany) connected to a motorized microinjection system (TransferMan, Eppendorf). Thus, after locating a piece of tissue with beating cilia the sample was secured to the bottom of the dish by the Eppendorf system. On each piece of tissue, the CBF of at least two different cells that were not adjacent to each other was measured in parallel. Only cells at the perimeter of the tissue were used for analysis.

\section{Detection system}

The CBF was measured using an inverted bright field microscope (Nikon TE-300, Nikon Instruments, Inc, New York) equipped with a $100 \times$ oil immersion objective (Numerical Aperture $=1.3$ ). The microscope objective was heated by an adjustable heater loop attached to the objective and regulated by a controller unit (Bioptechs, Butler, Pennsylvania). Images of the ciliary movement were acquired with a 12 bit high speed camera (Prosilica EC1020, Prosilica Inc, Burnaby, Canada) where a region of interest of approximately $50 \times 50$ pixels could be recorded with a speed of 100 frames per second. The spatial positions of cilia attached to a single cell were determined from the recorded images by a center-of-mass algorithm in LabView (National Instruments, Austin, TX). The center of mass for an image composed of several loose structures such as cilia is a point in space at 
which the cilia's whole mass can be considered to be concentrated to. This facilitates the calculation of the ciliary movement. Finally, the distribution of beat frequencies present was calculated through a fast Fourier transform (FFT) in which the recorded ciliary movements are decomposed into components of different frequencies.

\section{Characterization of assay and progesterone exposure}

To characterize the assay, individual variability as well as the influence of incubation time on the CBF was investigated. Progesterone ( $>99 \%$ purity, Sigma-Aldrich, St Louis, MO), was first dissolved in ethanol and then through further dilutions steps into G-MOPS ${ }^{\mathrm{m}}$. To add $\mathrm{P}_{4}$ to the cells, half of the medium in the dish was replaced with an equal volume of medium containing ethanol and $\mathrm{P}_{4}$, resulting in a final exposure concentration of $0.1 \%(\mathrm{v} /$ v) ethanol and $20 \mu \mathrm{M}$ or $100 \mathrm{nM} \mathrm{P}$. Control cells were exposed to ethanol $(0.1 \%(\mathrm{v} / \mathrm{v}))$ only. A pilot study was performed measuring the CBF during 20 minutes before and 20 minutes after replacing half of the medium. Similarly, the CBF was also studied in cells exposed to medium with $0.1 \%(\mathrm{v} / \mathrm{v})$ ethanol for $1.5 \mathrm{~h}$. No clear effect was observed neither by the replacement of medium nor by incubating the cells with ethanol (data not shown).

A baseline frequency for each cell was first assessed based on measurements every 5 minutes for 30 minutes, after which the drug was added together with medium. Then the CBF was recorded every 5 minutes for the following 60 minutes. In the cow, $\mathrm{P}_{4}$ affects the CBF within 15 minutes [7]. Our pilot experiments suggested a similar response time in mice, reaching stable values within 30 minutes. To allow a response to develop, the average CBF of the last 30 minutes of the recording period was therefore calculated and compared with the baseline frequency for each cell to assess the effect of added $\mathrm{P}_{4}$.

\section{Statistics}

The CBF data for the $20 \mu \mathrm{M}$ concentration was analyzed from 11 pieces of tissue exposed to progesterone and 8 control pieces exposed to ethanol only derived from in total 11 mice. The $\Delta$ frequency before and after treatment for each cell was calculated as the difference between the mean CBF during the last 30 minutes of the measurement and the mean baseline CBF during the first 30 minutes of the measurement. From each piece of tissue, the average $\Delta$ frequency of two cell replicates was used. As there was a predefined hypothesis that $\mathrm{P}_{4}$ lowers the CBF, a one sided Student's t-test was applied.

For the $100 \mathrm{nM}$ concentration the CBF data were analyzed from 16 pieces of tissue from 8 mice. In this experiment, we used a paired approach as we were able to include both control and progesterone exposed tissues from all animals, thereby improving the statistical power.
As the CBF varies between cells, the CBF for each cell was first normalized against its baseline CBF. For each piece of tissue an average CBF at each time point was calculated based on analyses of two cells per tissue. For each mouse the difference in CBF between the tissue exposed to progesterone and the control tissue was calculated. To test the effect of added $\mathrm{P}_{4}$, the mean differences for the first 30 minutes and the last 30 minutes were calculated for all eight individuals. As above there was a predefined hypothesis that $\mathrm{P}_{4}$ lowers the $\mathrm{CBF}$, thus a one sided paired student's t-test was applied.

\section{Results}

\section{Characterization of assay}

The imaging analyses gave a clear recording which, after Fourier-transformation, could be translated to a CBF (Figure 1). A mean baseline CBF (based on recording over the first 30 minutes) was calculated from 19 mice. The CBF prior to any treatment was $23.3 \pm 3.8 \mathrm{~Hz}$ (average \pm standard deviation) with a range from 16.8 to $31.9 \mathrm{~Hz}$. Figure 2 shows the mean frequency of the control cells from thirteen individuals measured every five minutes for 95 minutes and illustrates the variation that exist between different individuals and over time. Although the CBF differed between mice and between time points for individual mice, there was no clear trend of either a decrease or an increase in CBF during the 95 minute period of the analysis.

\section{Response to progesterone}

Exposure to $20 \mu \mathrm{M}$ progesterone significantly reduced the mean $\Delta$ frequency with $2.28 \mathrm{~Hz}$ corresponding to about $10 \%$ as compared with cells exposed to ethanol only ( $\mathrm{p}=0.034)$. The CBF of control cells exposed to ethanol only was reduced by, on average, $0.2 \mathrm{~Hz}$ comparing the end of the recording period with the baseline frequency (Figure 3). This reduction in frequency over time was not significantly different from zero $(\mathrm{p}=0.66$; one sample t-test). Similarly, $100 \mathrm{nM} \mathrm{P}_{4}$ significantly reduced the mean $\Delta$ frequency with $3.74 \mathrm{~Hz}$ corresponding to about $15 \%$ reduction compared to the frequency of the control cells $(\mathrm{p}=0.009)$ (Figure 4).

\section{Discussion}

We have used a light reflection-based method for recording CBF of epithelial cells of the mouse fallopian tube. Given the experimental conditions, the CBF was stable over a period of at least 95 minutes, allowing an establishment of a baseline CBF, addition of hormone, and a subsequent recording of the ciliary activity. Thus, we have established a procedure for studying the effects of different factors on the CBF in the mouse fallopian tube. 

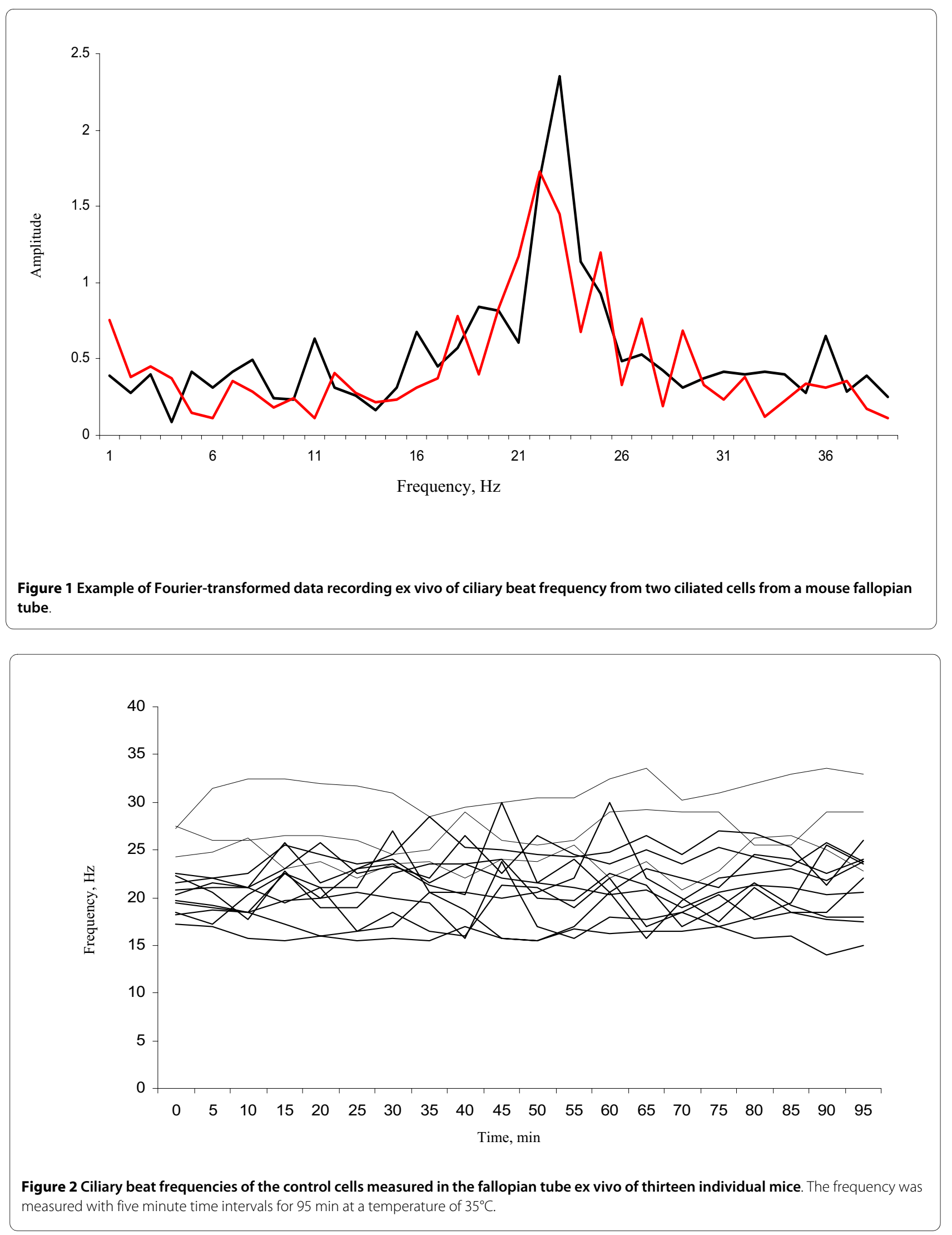


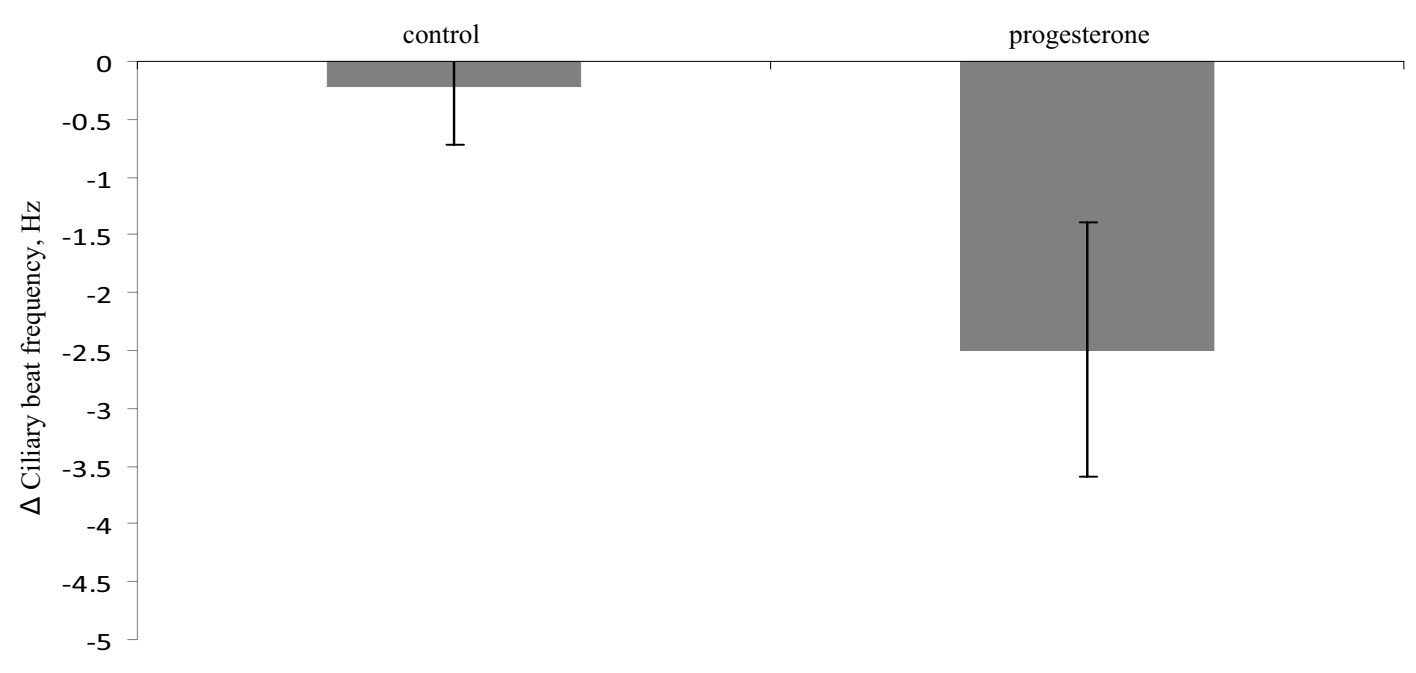

Figure 3 Mean decrease in beat frequency of ciliated cells from mouse fallopian tubes ex vivo, treated with ethanol only $(0.1 \%$; left bar) or with ethanol + progesterone $(20 \mu \mathrm{M}$; right bar). Error bars indicate the standard error of the mean.

The mean CBF was approximately $23.3 \pm 3.8 \mathrm{~Hz}$ in the mouse. In cows, a mean CBF of $23.1 \mathrm{~Hz}$ with a standard deviation of $4.7 \mathrm{~Hz}$ was reported [12], whereas in humans the baseline CBF ranges between 5 and $20 \mathrm{~Hz}[3,25]$. In some ex vivo studies, the CBF increased after several hours/days in culture $[3,26]$. The assessment of the baseline frequency is an important aspect in the evaluation of ciliary activity. A deviation from the normal CBF might in some cases relate to pathological conditions. The experimental conditions, including temperature, also have potential to affect the CBF. A lower assay temperature used in human studies to overcome effects on muscular contractility may partly explain the lower CBF reported for humans compared with both cows [12] and mice (present study).

Wessel et al. used a $\mathrm{P}_{4}$ concentration of $20 \mu \mathrm{M}$ [12]. The same concentration was used in the present mouse study. We found a significantly lowered CBF 30 minutes after addition of $20 \mu \mathrm{M} \mathrm{P}_{4}$ with about $2.28 \mathrm{~Hz}$ corresponding to $10 \%$ compared with the control cells. This is very similar to the results found in the cow, where $\mathrm{P}_{4}$ reduced the CBF by $11 \%$ within 15 minutes after adding $\mathrm{P}_{4}$. Twenty $\mu \mathrm{M}$ is a high concentration in relation to circulating serum levels, which normally range between $25-50 \mathrm{nM}$ in mice [27] and $1-10 \mathrm{nM}$ in humans [28]. Although the concentration of $\mathrm{P}_{4}$ has not yet been measured in the immediate vicinity of the traveling cumulus complex, it can be expected to be higher than the circulating levels, as the granulosa cells actively produce and secrete $\mathrm{P}_{4}$ within the fallopian tube in both mice and humans
$[29,30]$. Indeed, human spermatozoa are attracted to the radially distributed cumulus cells, i.e. granulosa cells surrounding the ovum, by chemotaxis, as these cells produce a $\mathrm{P}_{4}$ concentration gradient $[31,32]$. Thus, associating circulating levels of $\mathrm{P}_{4}$ with the change in CBF in the fallopian tube may therefore be of limited value $[4,22,25,33$ 36]. Still one can discuss if $20 \mu \mathrm{M}$ is a physiological relevant concentration since $P_{4}$ receptors, both PGR $\left(k_{d}=1-5\right.$ $\mathrm{nM}$ and $\mathrm{mPRs}\left(\mathrm{k}_{\mathrm{d}}=20-30 \mathrm{nM}\right.$ [13]) have affinities for $\mathrm{P}_{4}$ in the $\mathrm{nM}$ range. Using a concentration considerably higher than the affinity for the receptors might result in unspecific effects. Therefore, we also chose to study the effects of a concentration of $\mathrm{P}_{4}$ just above the $\mathrm{k}_{\mathrm{d}}$ of the receptors that may be involved in the response. The CBF was significantly reduced by $3.74 \mathrm{~Hz}$ corresponding to $15 \% 30$ minutes after addition of $100 \mathrm{nM} \mathrm{P}_{4}$. This reduction of CBF was very similar to the reduction by $20 \mu \mathrm{M}$ and also to the result seen in cow. Thus, there seem to be important and strong similarities in the response to $\mathrm{P}_{4}$ between the cow and the mouse. Given the relatively long evolutionary distance between cow and mouse within the mammalian taxon, this suggests that rapid effects of $\mathrm{P}_{4}$ on $\mathrm{CBF}$ in the fallopian tube most likely exist in other mammalian species as well.

The stimulation of sperm swimming is another example of rapid $\mathrm{P}_{4}$ regulation of ciliary or flagellary activity [19]. Neither in sperm nor in fallopian tube cilia does pretreatment with a nuclear $\mathrm{P}_{4}$ receptor antagonist prevent the rapid effects of $\mathrm{P}_{4}$, suggesting an action of $\mathrm{P}_{4}$ via different receptor system than the classical nuclear recep- 


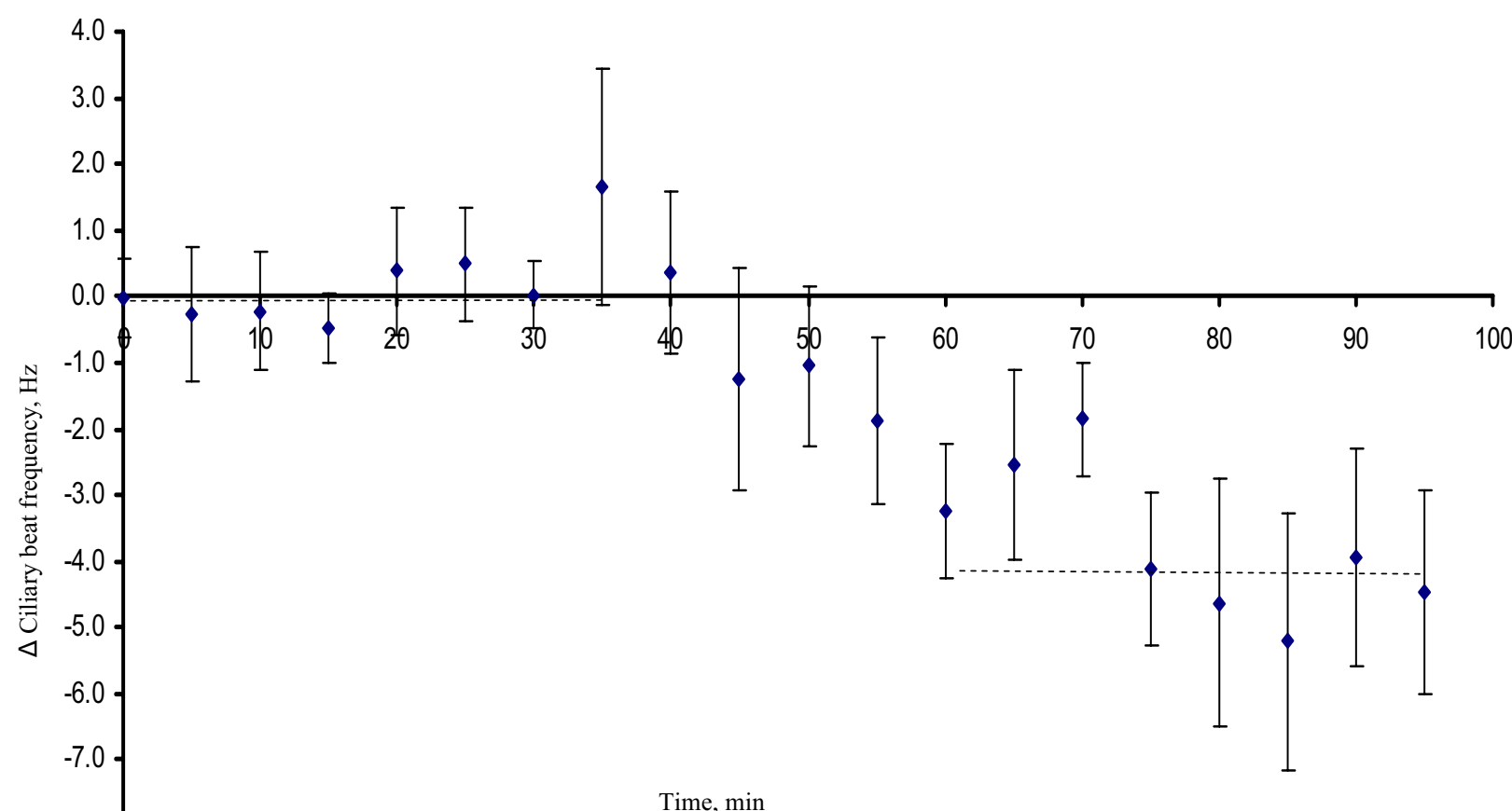

Figure 4 The average difference in CBF between cells exposed to $100 \mathrm{nM} \mathrm{P}_{4}$ and control cells based on sixteen fallopian tube samples from eight mice (paired comparisons). The CBF for each cell was first normalized against its baseline CBF. Progesterone was added after 30 minutes. For each individual mouse the difference between cells exposed to $\mathrm{P}_{4}$ and control cells was calculated for every time point. The mean differences over the first 30 minutes (baseline period) and the last 30 minutes are shown as crosshatched lines.

tors [12,37]. Furthermore the effects of $\mathrm{P}_{4}$ on sperm as well as fallopian tube cilia are too rapid to easily be explained by a genomic action, involving transcription and translation. Membrane progesterone receptors ( $\mathrm{mPR}$ alfa, beta and gamma) have been proposed to mediate these effects [19,20,38-40]. Furthermore, G-proteins that have been reported to mediate $\mathrm{P}_{4}$ action via the mPRs in many species and cell systems [41] have been identified in ciliated cells of the fallopian tube $[42,43]$. The present study is important in this context as it is the first study to link a rapid reduction of fallopian tube $\mathrm{CBF}$ by $\mathrm{P}_{4}$ with the presence of mPRs in the fallopian tube in the very same species. However, immunostaining to the nuclear progesterone receptor has also been reported on the ciliated cells of the fallopian tube in mice [44]. Interestingly, the staining was restricted to the actual cilia, and no staining was found in the nucleus, suggesting a non-classical function of the receptor. The presence of multiple progesterone receptor types outside of the nucleus provides alternative mechanisms for explaining the rapid actions of progesterone in these cells. Further mice studies with specific selective receptor agonists and antagonists, as well as using transgenic animals, would be useful in eluci- dating the signaling mechanism of $\mathrm{P}_{4}$ action in the fallopian tube of mammals.

\section{Conclusions}

Our study demonstrates that the mouse is a useful model for studying the fallopian tube CBF ex vivo. The rapid reduction in $\mathrm{CBF}$ by $\mathrm{nM}$ concentrations of progesterone suggests that the effect could be mediated via a nongenomic receptor mechanism, possibly involving mPRs. The similar result seen in both cow and mouse suggests that rapid effects of $\mathrm{P}_{4}$ on $\mathrm{CBF}$ in the fallopian tube most likely exist in other mammalian species as well.

\section{Competing interests}

The authors declare that they have no competing interests.

\section{Authors' contributions}

$A B$ carried out the tissue preparations and CBF measurements, analysed the data and participated in the writing of the manuscript. MN developed the method for tissue preparation and participated in the writing of the manuscript. RW did the technical set up for the detection system and the computer program for analysing the CBF readings. MG participated in the design and helped to draft the manuscript. DGJL conceived of the study and participated in its design and coordination, performed the statistical analysis and helped to draft the manuscript. MG, HB and DGJL supervised the study. All authors participated in the design of the study, read and approved the final manuscript. 


\section{Acknowledgements}

This work was supported by grants from the Swedish Research Council (VR medicine) and the Swedish Research Council for Environment, Agricultural Sciences and Spatial Planning (FORMAS) to D.G.J. Larsson, the Adlebertska Research Foundation to A. Bylander and the Emil and Maria Palm's Research Foundation and the Rådman and Fru Ernst Colliander's Foundation to M. Nutu.

\section{Author Details}

1Institute of Neuroscience and Physiology, the Sahlgrenska Academy, University of Gothenburg, SE-405 30 Göteborg, Sweden and 2Department of Physics, University of Gothenburg, SE-412 96 Göteborg, Sweden

Received: 26 February 2010 Accepted: 15 May 2010

Published: 15 May 2010

\section{References}

1. Halbert SA, Becker DR, Szal SE: Ovum transport in the rat oviductal ampulla in the absence of muscle contractility. Biol Reprod 1989, 40(6):1131-1136.

2. Halbert SA, Tam PY, Blandau RJ: Egg transport in the rabbit oviduct: the roles of cilia and muscle. Science 1976, 191(4231):1052-1053.

3. Mahmood T, Saridogan E, Smutna S, Habib AM, Djahanbakhch O: The effect of ovarian steroids on epithelial ciliary beat frequency in the human Fallopian tube. Hum Reprod 1998, 13(11):2991-2994.

4. Lyons RA, Djahanbakhch O, Mahmood T, Saridogan E, Sattar S, Sheaff MT, Naftalin AA, Chenoy R: Fallopian tube ciliary beat frequency in relation to the stage of menstrual cycle and anatomical site. Hum Reprod 2002, 17(3):584-588.

5. Lyons RA, Saridogan E, Djahanbakhch O: The effect of ovarian follicular fluid and peritoneal fluid on Fallopian tube ciliary beat frequency. Hum Reprod 2006, 21(1):52-56.

6. Blandau RJ, Boling JL, Halbert S, Verdugo P: Methods for studying oviductal physiology. Gynecol Invest 1975, 6(3-4):123-145.

7. Papathanasiou A, Djahanbakhch O, Saridogan E, Lyons RA: The effect of interleukin- 6 on ciliary beat frequency in the human fallopian tube. Fertil Steril 2008, 90(2):391-394.

8. Spilman $\mathrm{CH}$, Harper MJ: Effects of prostaglandins on oviductal motility and egg transport. Gynecol Invest 1975, 6(3-4):186-205.

9. Wanggren K, Lalitkumar PG, Stavreus-Evers A, Stabi B, Gemzell-Danielsson $\mathrm{K}$ : Prostaglandin E2 and F2alpha receptors in the human Fallopian tube before and after mifepristone treatment. Mol Hum Reprod 2006, 12(9):577-585

10. Saridogan E, Djahanbakhch O, Puddefoot JR, Demetroulis C, Collingwood K, Mehta JG, Vinson GP: Angiotensin II receptors and angiotensin II stimulation of ciliary activity in human fallopian tube. J Clin Endocrinol Metab 1996, 81(7):2719-2725.

11. Verdugo $\mathrm{P}: \mathrm{Ca} 2+-$ dependent hormonal stimulation of ciliary activity. Nature 1980, 283(5749):764-765.

12. Wessel $\mathrm{T}$, Schuchter $\mathrm{U}$, Walt $\mathrm{H}$ : Ciliary motility in bovine oviducts for sensing rapid non-genomic reactions upon exposure to progesterone. Horm Metab Res 2004, 36(3):136-141

13. Zhu Y, Bond J, Thomas P: Identification, classification, and partial characterization of genes in humans and other vertebrates homologous to a fish membrane progestin receptor. Proc Natl Acad Sci USA 2003, 100(5):2237-2242.

14. Zhu $Y$, Rice $C D$, Pang $Y$, Pace $M$, Thomas $P$ : Cloning, expression, and characterization of a membrane progestin receptor and evidence it is an intermediary in meiotic maturation of fish oocytes. Proc Nat/ Acad SciUSA 2003, 100(5):2231-2236.

15. Pace MC, Thomas P: Activation of a pertussis toxin-sensitive, inhibitory $\mathrm{G}$-protein is necessary for steroid-mediated oocyte maturation in spotted seatrout. Dev Biol 2005, 285(1):70-79.

16. Qiu HB, Lu SS, Ji KL, Song XM, Lu YQ, Zhang M, Lu KH: Membrane progestin receptor beta (mPR-beta): A protein related to cumulus expansion that is involved in in vitro maturation of pig cumulus-oocyte complexes. Steroids 2008, 73(14):1416-1423.

17. Sleiter N, Pang Y, Park C, Horton TH, Dong J, Thomas P, Levine JE: Progesterone receptor $\mathrm{A}$ (PRA) and PRB-independent effects of progesterone on GnRH release. Endocrinology 2009, 150(8):3833-3844

18. Karteris E, Zervou S, Pang Y, Dong J, Hillhouse EW, Randeva HS, Thomas P: Progesterone signaling in human myometrium through two novel membrane $G$ protein-coupled receptors: potential role in functional progesterone withdrawal at term. Mol Endocrinol 2006,

20(7):1519-1534.

19. Tubbs $C$, Thomas $P$ : Progestin signaling through an olfactory $G$ protein and membrane progestin receptor-alpha in Atlantic croaker sperm: potential role in induction of sperm hypermotility. Endocrinology 2009, 150(1):473-484

20. Nutu M, Weijdegard B, Thomas P, Bergh C, Thurin-Kjellberg A, Pang Y, Billig $H$, Larsson DGJ: Membrane progesterone receptor gamma: tissue distribution and expression in ciliated cells in the fallopian tube. Mol Reprod Dev 2007, 74(7):843-850.

21. Nutu MWB, Thomas P, Thurin-Kjellberg A, Billig H, Larsson DGJ: Distribution and hormonal regulation of membrane progesterone receptors beta and gamma in ciliated epithelial cells of mouse and human fallopian tubes. Reprod Biol Endocrinol 2009, 7:89.

22. Borell $U$, Nilsson $\mathrm{O}$, Westman A: Ciliary activity in the rabbit fallopian tube during oestrus and after copulation. Acta Obstet Gynecol Scand 1957, 36(1):22-28

23. Croxatto HB: Physiology of gamete and embryo transport through the fallopian tube. Reprod Biomed Online 2002, 4(2):160-169,

24. Paltieli Y, Eibschitz I, Ziskind G, Ohel G, Silbermann M, Weichselbaum A: High progesterone levels and ciliary dysfunction--a possible cause of ectopic pregnancy. J Assist Reprod Genet 2000, 17(2):103-106.

25. Westrom L, Mardh PA, Mecklenburg CV, Hakansson CH: Studies on ciliated epithelia of the human genital tract. II. The mucociliary wave pattern of fallopian tube epithelium. Fertil Steril 1977, 28(9):955-961.

26. Morales P, Palma V, Salgado AM, Villalon M: Sperm interaction with human oviductal cells in vitro. Hum Reprod 1996, 11(7):1504-1509.

27. Walmer DK, Wrona MA, Hughes CL, Nelson KG: Lactoferrin expression in the mouse reproductive tract during the natural estrous cycle: correlation with circulating estradiol and progesterone. Endocrinology 1992, 131(3):1458-1466

28. Tang Y, Gong F, Lin G, Lu G: Early follicular progesterone concentrations and in vitro fertilization pregnancy outcomes. Fertil Steril 2007, 87(4):991-994.

29. Vanderhyden BC, Tonary AM: Differential regulation of progesterone and estradiol production by mouse cumulus and mural granulosa cells by A factor(s) secreted by the oocyte. Biol Reprod 1995, 53(6):1243-1250.

30. Bar-Ami S, Gitay-Goren H, Brandes JM: Different morphological and steroidogenic patterns in oocyte/cumulus-corona cell complexes aspirated at in vitro fertilization. Biol Reprod 1989, 41(4):761-770.

31. Teves ME, Barbano F, Guidobaldi HA, Sanchez R, Miska W, Giojalas LC: Progesterone at the picomolar range is a chemoattractant for mammalian spermatozoa. Fertil Steril 2006, 86(3):745-749.

32. Baltes P, Sanchez R, Pena P, Villegas J, Turley H, Miska W: Evidence for the synthesis and secretion of a CBG-like serpin by human cumulus oophorus and fallopian tubes. Andrologia 1998, 30(4-5):249-253.

33. Lyons RA, Djahanbakhch O, Saridogan E, Naftalin AA, Mahmood T, Weekes A, Chenoy R: Peritoneal fluid, endometriosis, and ciliary beat frequency in the human fallopian tube. Lancet 2002, 360(9341):1221-1222.

34. Critoph FN, Dennis KJ: Ciliary activity in the human oviduct. Obstet Gynecol Surv 1977, 32(7):602-603.

35. Kugler P, Wrobel KH, Wallner HJ, Heinzmann U: [Histochemical and histological investigations on the human fallopian tube under different hormonal influences. I. Demonstration of ATPase with special reference to reactive ciliated cells (author's transl)]. Arch Gynakol 1976, 221(4):345-366

36. Kugler $\mathrm{P}$, Wrobel KH, Wallner HJ, Heinzmann U: [Histochemical and histological investigations on the human Fallopian tube under different hormonal influences. II. Proliferative processes within endosalpingeal epithelium (author's transl)]. Arch Gynakol 1977, 222(3):197-211.

37. Uhler ML, Leung A, Chan SY, Wang C: Direct effects of progesterone and antiprogesterone on human sperm hyperactivated motility and acrosome reaction. Fertil Steril 1992, 58(6):1191-1198.

38. Thomas $P$, Pang $Y, Z$, hu Y, Detweiler C, Doughty K: Multiple rapid progestin actions and progestin membrane receptor subtypes in fish. Steroids 2004, 69(8-9):567-573

39. Tubbs $C$, Pace $M$, Thomas P: Expression and gonadotropin regulation of membrane progestin receptor alpha in Atlantic croaker (Micropogonias undulatus) gonads: Role in gamete maturation. Gen Comp Endocrinol 2009, 165(1):144-54. 
40. Thomas P, Tubbs C, Garry VF: Progestin functions in vertebrate gametes mediated by membrane progestin receptors (mPRs): Identification of mPRalpha on human sperm and its association with sperm motility. Steroids 2009, 74(7):614-621.

41. Tubbs $C$, Thomas P: Functional characteristics of membrane progestin receptor alpha (mPRalpha) subtypes: a review with new data showing $\mathrm{mPRalpha}$ expression in seatrout sperm and its association with sperm motility. Steroids 2008, 73(9-10):935-941.

42. Monkkonen KS, Aflatoonian R, Lee KF, Yeung WS, Tsao SW, Laitinen JT, Fazeli A: Hormonal regulation of Galphai2 and mPRalpha in immortalized human oviductal cell line OE-E6/E7. Mol Hum Reprod 2007, 13(12):845-851.

43. Monkkonen KS, Aflatoonian R, Lee KF, Yeung WS, Tsao SW, Laitinen JT, Tuckerman EM, Li TC, Fazeli A: Localization and variable expression of $G$ alpha(i2) in human endometrium and Fallopian tubes. Hum Reprod 2007, 22(5):1224-1230.

44. Teilmann SC, Clement CA, Thorup J, Byskov AG, Christensen ST:

Expression and localization of the progesterone receptor in mouse and human reproductive organs. JEndocrinol 2006, 191(3):525-535.

doi: $10.1186 / 1477-7827-8-48$

Cite this article as: Bylander et al., Rapid effects of progesterone on ciliary beat frequency in the mouse fallopian tube Reproductive Biology and Endocrinology 2010, 8:48

Submit your next manuscript to BioMed Central and take full advantage of:

- Convenient online submission

- Thorough peer review

- No space constraints or color figure charges

- Immediate publication on acceptance

- Inclusion in PubMed, CAS, Scopus and Google Scholar

- Research which is freely available for redistribution

Submit your manuscript at www.biomedcentral.com/submit
Ciomed Central 